\title{
Gene expression and enzymatic activity of pectin methylesterase during fruit development and ripening in Coffea arabica $\mathrm{L}$.
}

\author{
S.M.B. Cação ${ }^{1}$, T.F. Leite ${ }^{1}$, I.G.F. Budzinski ${ }^{1}$, T.B. dos Santos ${ }^{1}$, \\ M.B.S. Scholz ${ }^{1}$, V. Carpentieri-Pipolo ${ }^{2}$, D.S. Domingues ${ }^{1}$, \\ L.G.E. Vieira ${ }^{1}$ and L.F.P. Pereira ${ }^{3}$
}

${ }^{1}$ Laboratório de Biotecnologia Vegetal, Instituto Agronômico do Paraná, Londrina, PR, Brasil

${ }^{2}$ Departamento de Agronomia, Centro de Ciências Agrárias, Universidade Estadual de Londrina, Londrina, PR, Brasil

${ }^{3}$ EMBRAPA Café, Londrina, PR, Brasil

Corresponding author: L.F.P. Pereira

E-mail: filipe.pereira@embrapa.br

Genet. Mol. Res. 11 (3): 3186-3197 (2012)

Received March 26, 2012

Accepted July 25, 2012

Published September 3, 2012

DOI http://dx.doi.org/10.4238/2012.September.3.7

\begin{abstract}
Coffee quality is directly related to the harvest and post harvest conditions. Non-uniform maturation of coffee fruits, combined with inadequate harvest, negatively affects the final quality of the product. Pectin methylesterase (PME) plays an important role in fruit softening due to the hydrolysis of methylester groups in cell wall pectins. In order to characterize the changes occurring during coffee fruit maturation, the enzymatic activity of PME was measured during different stages of fruit ripening. PME activity progressively increased from the beginning of the ripening process to the cherry fruit stage. In silico analysis of expressed sequence tags of the Brazilian Coffee Genome Project database identified 5 isoforms of $P M E$. We isolated and cloned a cDNA homolog of PME for further characterization. CaPME4 transcription was analyzed in pericarp, perisperm, and endosperm tissues during fruit development and ripening as well as in other plant tissues.
\end{abstract}


Northern blot analysis revealed increased transcription of CaPME4 in the pericarp 300 days after flowering. Low levels of CaPME4 mRNAs were observed in the endosperm 270 days after flowering. Expression of $C a P M E 4$ transcripts was strong in the branches and lower in root and flower tissues. We showed that CaPME4 acts specifically during the later stages of fruit ripening and possibly contributes to the softening of coffee fruit, thus playing a significant role in pectin degradation in the fruit pericarp.

Key words: Coffee; Maturation; Quality; PME; Gene expression

\section{INTRODUCTION}

Coffee is one of the most important agricultural commodities and is widely cultivated in tropical countries. Commercial production relies on two species, Coffea arabica L. and $C$. canephora Pierre ex Froehner, which represent about 70 and 30\% of the total coffee market, respectively (Vieira et al., 2006). The "cup quality" of coffee is directly associated with the ripening stage of the fruits during harvesting (Montavon et al., 2003). Inadequate harvesting and post-harvesting practices, including the mixing of coffee berries at different ripening stages (i.e., green fruits and over-ripe fruits in the same batch of cherries), may negatively affect the quality of coffee by altering the acidity and bitterness (Rena et al., 1996). One possible strategy for obtaining fruits in the same stage of ripening is to use selective harvesting techniques; however, this is an expensive practice (Rena et al., 1996). Another approach is the use of coffee plants with uniform ripening, which would facilitate mechanical harvesting of high-quality beans (Ribas et al., 2006).

Fruit ripening is a highly coordinated and genetically programmed phenomenon that leads to the development of a fruit with specific desirable attributes (Prasanna et al., 2007). Fruit ripening is also associated with textural alterations, which are dramatic in climacteric fruits such as coffee (Pereira et al., 2005). The major textural changes that cause softening of fruit result from enzyme-mediated alterations in the structure and composition of the cell wall and partial or complete solubilization of cell wall polysaccharides, such as pectins (Prasanna et al., 2007).

Pectins, the major constituent of the primary cell wall in higher plants, are a heterogeneous group of polymers, of which homogalacturonan is the most important. They are synthesized in the Golgi apparatus and are secreted into the wall in a highly methylesterified state (reviewed by Micheli, 2001). Pectin methylesterases (PMEs) catalyze the removal of methyl esters from the linear homogalacturonan backbone within cell walls, which releases methanol and protons, thus remodeling its fine structure and affecting its susceptibility to subsequent enzymatic and non-enzymatic reactions (e.g., pectin depolymerization) and gel formation (Jolie et al., 2010).

PMEs are ubiquitous enzymes involved in various physiological processes associated with both vegetative and reproductive plant development. Several studies have shown a strong correlation between PME activity or PME gene expression and physiological processes, such as hypocotyl elongation (Derbyshire et al., 2007), fruit ripening and maturation (Tieman and Handa, 1994; Prasanna et al., 2007), cellular adhesion (Roberts et al., 2000), seed germination 
(Ren and Kermode, 2000), cambial cell differentiation (Micheli et al., 2000), and cell growth in developing wood cells (Siedlecka et al., 2008).

PME isoforms are encoded by large multi-gene families in all plant species. On the basis of phylogenetic analyses, they can be classified into 8 major clades (Markovic and Janecek, 2004). Their enzymatic and/or transcriptional activity have been reported in several tissues: fruits, leaves, flowers, stems, and roots. Some isoforms are constitutively expressed throughout the plant, whereas others are tightly regulated in specific tissues (pollen, fruits, or roots) or developmental stages (fruit ripening, microsporogenesis, or germination) (Jolie et al., 2010).

During fruit softening, pectins and hemicelluloses typically undergo solubilization and depolymerization, which contribute to cell wall loosening and disassembly (Wakabayashi et al., 2000). Changes in the pectin matrix are important for regulating the cell wall structure during fruit ripening and senescence. In this context, PME activity constitutes a key control point for both the assembly and disassembly of pectin networks (Brummel et al., 2004).

Coffee fruits have a high percentage of pectins in their pericarp (Pimenta et al., 2000). Changes in PME activity associated with fruit maturation may affect harvesting practices and post-harvesting operations (drying, de-pulping, etc.) to directly affect cup quality. Therefore, the objective of this study was to investigate the role of PME during coffee fruit ripening. Accordingly, we identified PME isoforms using the available expressed sequence tags (ESTs) from the Brazilian Coffee Genome Project database. One PME isoform was selected (CaPME4) for detailed analysis of transcriptional activity during development and ripening of C. arabica fruits concomitantly with enzymatic activity.

\section{MATERIAL AND METHODS}

\section{Search for $C$. arabica PME sequences}

In silico identification of $C$. arabica putative PME unigenes followed similar steps as those described in Budzinski et al. (2011). ESTs coding for PME were selected from the database of the Brazilian Coffee Genome Project (http://www.lge.ibi.unicamp.br/cafe) using a key word search. This EST database contains 130,792 ESTs of C. arabica, 12,381 ESTs of C. canephora, and 10,566 ESTs of C. racemosa. They are distributed into 37 cDNA libraries sequenced from the 5'-end (Vieira et al., 2006; Mondego et al., 2011). After BLAST searches in the coffee EST database, all singlets and contigs of candidate PME unigenes were re-assembled using Sequencher 4.2 (Gene Codes Corporation, Ann Arbor, MI, USA). The unigenes were then compared with those in the NCBI database using BLASTX and BLASTP (http://www. ncbi.nlm.nih.gov/BLAST; Altschul et al., 1997). The open reading frame (ORF) of each unigene was predicted using the ORF finder program (NCBI), and the deduced amino acid sequences were used to construct a phylogenetic tree to analyze the relationship between CaPMEs and other full-length PME genes. The full-length CaPME1, 2, 3, 4, and 5 cDNA nucleotide sequences were submitted to GenBank with the accession Nos. JN863078 (CaPME1), JN863079 (CaPME2), JN863080 (CaPME3), JN863081 (CaPME4), and JN863082 (CaPME5).

\section{Phylogenetic classification}

Five coffee PMEs with transcripts in fruit libraries were selected for analysis based 
on the phylogenetic classification of PMEs proposed by Markovic and Janecek (2004). The tree with the highest log likelihood was inferred using the maximum likelihood method based on the Poisson correction model and 1000 bootstrap replicates. Evolutionary analyses were conducted in MEGA5 (Tamura et al., 2011).

\section{Plant material}

Fruits in different stages of ripening and other plant tissues (roots, branches, leaves, flower buds, and flowers) were collected from C. arabica cv. IAPAR-59 plants cultivated under field conditions at the Agronomic Institute of Paraná Experimental Station (Londrina, Brazil) from December 2006 to April 2007. Fruits were collected every 90 days after flowering until complete maturation and were separated by perisperm color as previously described (Budzinski et al., 2011). Unless otherwise stated, experiments were conducted at least twice with a minimum of 3 biological replicates per experiment. After harvesting, all samples were immediately frozen in liquid nitrogen and stored at $-80^{\circ} \mathrm{C}$ until RNA extraction.

\section{RNA extraction}

To analyze CaPME4 transcription patterns, total RNA from different plant organs and fruit tissues (pericarp, perisperm, and endosperm) at several developmental stages were extracted as described by Geromel et al. (2006). RNA quality was checked on 1\% agarose gel electrophoresis, and total RNA quantification was performed using a Qubit fluorometer (Invitrogen, Carlsbad, CA, USA).

\section{Isolation of a partial $\mathrm{CaPME} 4 \mathrm{cDNA}$ clone}

A partial sequence corresponding to $C a P M E 4 \mathrm{cDNA}$ was amplified from mature whole fruit (cherry pericarp) for further use as a probe in Northern blot analysis. First-strand cDNA was synthesized from $1 \mu \mathrm{g}$ total RNA using the ThermoScript ${ }^{\mathrm{TM}}$ RT-PCR System (Invitrogen) according to manufacturer instructions. To amplify the CaPME4 ORF, specific primers were designed using Primer Designer 2.0: $\mathrm{CaPME}$ sense: 5'-CTC ATC GTT GGA AGT GGT GGT GG-3' and antisense: 5'-CTG TAA TCT CCG CTG CCA TCC T-3'. PCR was performed under the following conditions: initial denaturation at $94^{\circ} \mathrm{C}$ for $5 \mathrm{~min}$; followed by 40 cycles of $94^{\circ} \mathrm{C}$ for $1 \mathrm{~min}, 60^{\circ} \mathrm{C}$ for $45 \mathrm{~s}$, and $72^{\circ} \mathrm{C}$ for $1 \mathrm{~min}$, and a final extension step of $72^{\circ} \mathrm{C}$ for $5 \mathrm{~min}$ using standard Taq Polymerase (Invitrogen, Brazil). Reaction products were analyzed on a 1\% agarose gel. The amplified DNA fragment of $743 \mathrm{bp}$ was cloned into pTOPO2.1 (Invitrogen) and inserted into Escherichia coli TOP10 cells. Plasmid DNA was prepared by alkaline lysis and column-purified (Qiagen, Chatsworth, CA, USA), and both strands of the cloned cDNA fragments were sequenced with a MegaBACE 1000 DNA Analysis System (GE Life Science, Pittsburg, PA, USA).

\section{Northern blot analysis}

Total RNA $(15 \mu \mathrm{g})$ was denatured in 12.55 M formamide, 2.2 M formaldehyde, and 
$20 \mathrm{mM}$ 3-(N-morpholino)-propanesulfonic acid (MOPS) buffer at $\mathrm{pH} 7.0$ (also containing $5 \mathrm{mM} \mathrm{Na}$-acetate and $0.1 \mathrm{mM}$ EDTA) at $65^{\circ} \mathrm{C}$ for $15 \mathrm{~min}$ and fractionated on a $1.2 \%(\mathrm{w} / \mathrm{v})$ agarose gel containing $2.2 \mathrm{M}$ formaldehyde in 10X MOPS buffer. The RNA was transferred to nylon membranes by capillarity according to Sambrook et al. (1989). Membranes were prehybridized at $37^{\circ} \mathrm{C}$ for $2 \mathrm{~h}$ using UltraHyb ${ }^{\circledR}$ buffer (Ambion). The cDNA fragment of $\mathrm{CaPME4}$ was used as a template for probe synthesis. The probe was radiolabeled with $\left[\alpha-\mathrm{P}^{32}\right]-\mathrm{dCTP}$ by random priming, and membranes were hybridized at $37^{\circ} \mathrm{C}$ overnight in the same buffer. After hybridization, membranes were sequentially washed twice in 2 X SSC with $0.1 \%$ SDS for 10 min at $42^{\circ} \mathrm{C}$ and twice in $0.1 \mathrm{X} \mathrm{SSC}$ with $0.1 \%$ SDS for $10 \mathrm{~min}$ at $42^{\circ} \mathrm{C}$ before exposure to a BAS-IP MS 2340 imaging plate. Images were captured using a fluorescent image analyzer FLA 3000 (Fuji Photo Film Co., Ltd., Tokyo, Japan).

\section{PME extraction}

The PME extractions were carried out during 5 different stages of fruit ripening [120, $210,240,270$, and 300 days after flowering (DAF)] from green to the full-ripe cherry in order to analyze the biochemical activity of PME in the pericarp. Tissue samples were extracted in $50 \mathrm{mM}$ borate-acetate buffer at $\mathrm{pH} 7.5$ with $0.1 \mathrm{M} \mathrm{NaCl}$ solution at $4^{\circ} \mathrm{C}$. The ratio of coffee material to extractant was 1:3 (w/v). The homogenate was squeezed through two layers of gauze, and the extract was centrifuged for $10 \mathrm{~min}$ at $10,000 \mathrm{~g}$ to remove the solid particles (Körner et al., 1980). The supernatant was brought to $70 \%$ saturation by addition of solid ammonium sulfate and centrifuged at $10,000 \mathrm{~g}$ for $10 \mathrm{~min}$ after standing for $1 \mathrm{~h}$. The precipitate was resuspended in borate-acetate buffer at a ratio of $1: 3(\mathrm{w} / \mathrm{v})$.

\section{Determination of PME activity}

PME activity was measured titrimetrically by estimating the free carboxyl groups formed in pectin as a result of enzymatic action. The amount of $0.1 \mathrm{M} \mathrm{NaOH}$ required to maintain the median reaction at $\mathrm{pH} 7.5\left(25^{\circ} \mathrm{C}\right)$ was measured by the method described by Kertesz (1955). The enzyme substrate was a $0.5 \%$ citrus pectin solution (Sigma) containing $0.15 \mathrm{M}$ $\mathrm{NaCl}$. One unit of PME was defined as the amount of enzyme that released $1 \mathrm{mmol}$ carboxyl groups $\min ^{-1} \cdot \mathrm{g}^{-1}$ fresh weight of pericarp.

\section{RESULTS AND DISCUSSION}

\section{In silico analysis}

Data mining of the Brazilian Coffee Genome database (http://www.lge.ibi.unicamp. $\mathrm{br} / \mathrm{cafe} /$ ) yielded 162 candidate sequences that corresponded to annotated PME sequences. After local clustering, 5 contigs with ESTs were formed from fruit libraries, named CaPME1 to CaPME5 (Table 1). A similarity analysis of the selected cDNAs indicated that they were unique sequences representing different PME genes. After translation and conserved domain analysis, it was possible to identify 2 characteristic PME domains [Pfam01095 pectinesterase superfamily and Pfam04043 PMEI (inhibitor) superfamily]. CaPME1 and CaPME4 have both domains, while CaPME2, CaPME3, and CaPME5 have only the domain, Pfam 01095. The 
domain Pfam 01095 domain matches the pre-region that is required for protein targeting to the endoplasmic reticulum (Micheli, 2001; Dorokhov et al., 2006). Targeting to the endomembrane system leads to the export of PMEs into the cell wall and is mediated either by a common type signal peptide or a transmembrane domain (signal anchor). The pro-region (Pfam 04043) shares similarities with the PMEI domain and is thought to play an autoinhibitory role during the enzyme's secretion into the apoplast, where only the mature part of the protein is found (Giovane et al., 2004).

Table 1. Pectin methylesterase (PME) contigs with expressed sequence tags (ESTs) from fruit libraries.

\begin{tabular}{lll}
\hline PME & Coffea arabica contigs (Mondego et al., 2011) & FR ESTs (Mondego et al., 2011)* \\
\hline CaPME1 & Contig 521 & 3 FR ESTs/15 ESTs total \\
CaPME2 & Contig 4211 & FR ESTs/6 ESTs total \\
CaPME3 & Contig 15241 & 1 FR ESTs $/ 3$ ESTs total \\
CaPME4 & Contig 13700 & 5 FR ESTs $/ 14$ ESTs total \\
CaPME5 & Contig 14456 & 4 FR ESTs $/ 2$ ESTs total \\
\hline
\end{tabular}

*Number of ESTs from fruit libraries/total ESTs from contig.

The deduced amino acid sequences of $C$. arabica and other known plant pectin methyesterases were aligned, and a phylogenetic tree was drawn to classify Coffea PMEs (Figure 1). Phylogenetic analysis showed that Coffea PMEs are distributed in 5 of the 9 clades assigned for plant PMEs (Markovic and Janecek, 2004). CaPME1 (587 amino acids, aa) is classified into clade Plant1. This isoform has all characteristics described for this clade: a conserved segment, WPxWxxxxDRRLLQ, and a length between 520 and 590 residues. We identified all 5 conserved domains listed by Markovic and Janecek (2004), with only a single substitution in one residue of region III (Table 2). CaPME2 (355 aa) is classified into clade Plant2a and contains the main features of this group: a conserved segment, PxWxxxxDRRLL, and one conserved histidine (His/H) preceding the mature enzyme. CaPME2 has identical conserved regions in comparison to Q9M3B0_ARATH34 (Table 2), including a conserved segment, RR. CaPME3 (273 aa) and other members of the Plant X2 clade do not contain the pre-pro region. This isoform also has a His residue that is conserved in PMEs of the Plant X2 clade and 4 of the 5 conserved PME regions (Table 2). CaPME5 is grouped into clade Plant 1a, the largest plant clade (Markovic and Janecek, 2004). This PME has 325 residues and, although it is unusually small in length, contains all 5 conserved regions present in PMEs.

CaPME4 (582 aa) is classified into the clade Plant 3 that originally contained only 2 PMEs (Q43867_ARATH and Q43111_PHAVU). All features of this clade, such as typical length and 5 conserved regions, are observed in CaPME4 (Table 2). Since this isoform was selected for further transcriptional analysis, details of its transmembrane domains and the pre- and pro-regions are depicted in Figure 2.

On the basis of the in silico analysis for identifying transcriptionally active PMEs in the CafEST database, we observed that CaPME4 is the unigene that contains the largest number of reads from the fruit-specific cDNA library (5 reads, Table 1$)$. Therefore, we chose this isoform for RNA analysis in order to gain insight into the transcription pattern of CaPME during coffee fruit development and maturation. 


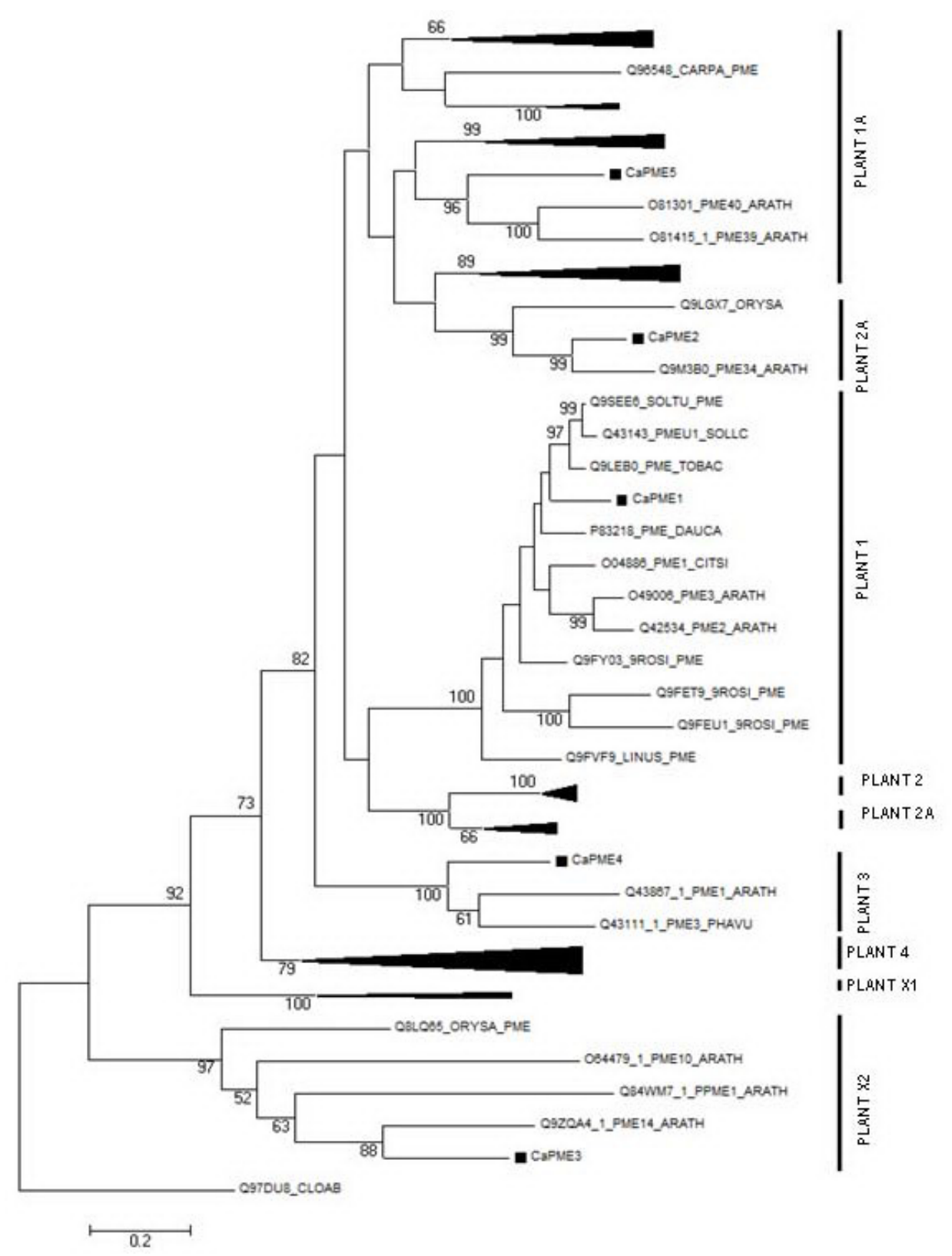

Figure 1. Phylogenetic analysis of Coffea pectin methylesterases (PMEs). The tree with the highest log likelihood was inferred by using the maximum likelihood method based on the Poisson correction model, and 1000 bootstrap replicates. Bootstrap values over 50\% are shown. The analysis involved 48 protein sequences. All positions with less than $80 \%$ site coverage were eliminated. There were a total of 401 positions in the final dataset. Evolutionary analyses were conducted in MEGA5 (Tamura et al., 2011). Vertical lines indicate the 8 clades (Plant 1A, 2A, 1, 2, 3, 4, X1, and X2). Black boxes indicate coffee PMEs (CaPME1, 2, 3, 4, and 5) identified in the coffee database. 
Table 2. Segments of conserved amino acid of Coffea pectin methylesterases (PMEs): CaPME1 to CaPME5.

\begin{tabular}{|c|c|c|c|c|c|c|}
\hline Clade & Accession/gene & Region I & Region II & Region III & Region IV & Region V \\
\hline \multirow[t]{2}{*}{ Plant1 } & P83218_DAUCA & 94GVYREN & 112HQVALR & 134YQDTLYV & 157DFIFG & 223LGRPWK \\
\hline & CaPMË & GVYREN & HQVALR & HQDTLYA & DFIFG & LGRPWK \\
\hline \multirow[t]{2}{*}{ Plant2a } & Q9M3BO_ARATH34 & 320GKYEED & 386HQAVALR & 410YQDTLYV & 433DFIFG & 499LGRPWK \\
\hline & CaPME2 & GKYEED & HQAVALR & YQDTLYV & DFIFG & LGRPWK \\
\hline \multirow[t]{2}{*}{ Plantx2 } & Q8LQ65_ORYSA11 & 121GTYTEK & 201KQAVALR & 223AQDTLYD & 246DFIFG & 300LGRAWG \\
\hline & CaPME3 & Not found & AQAVALR & AQDTLND & DFIFG & LGRAWG \\
\hline \multirow[t]{2}{*}{ Plant3 } & Q43867_ARATH65 & 316GTYVEN & 384HQAVAFR & 406FQDTLYP & 429DFIFG & 490LGRPWK \\
\hline & CaPME $\overline{4}$ & GVYKEK & HQAVAFR & FQDTLYP & DFIFG & LGRPWK \\
\hline \multirow[t]{2}{*}{ Plant1a } & O04889_CITSI2 & 238GTYNEN & 306HQAVALR & 328YQDTLYV & 351DFIFG & 417LGRPWK \\
\hline & CaPME $\overline{5}$ & GAYFEY & HQAVALR & YQDTLYV & DFIFG & LGRPWK \\
\hline
\end{tabular}

The segments are arranged into the clades: Plant1, 2a, x2, 3, 1a. The numbers in front of the segments indicate the position in the amino acid sequences based on Markovic and Janecek (2004) classification.

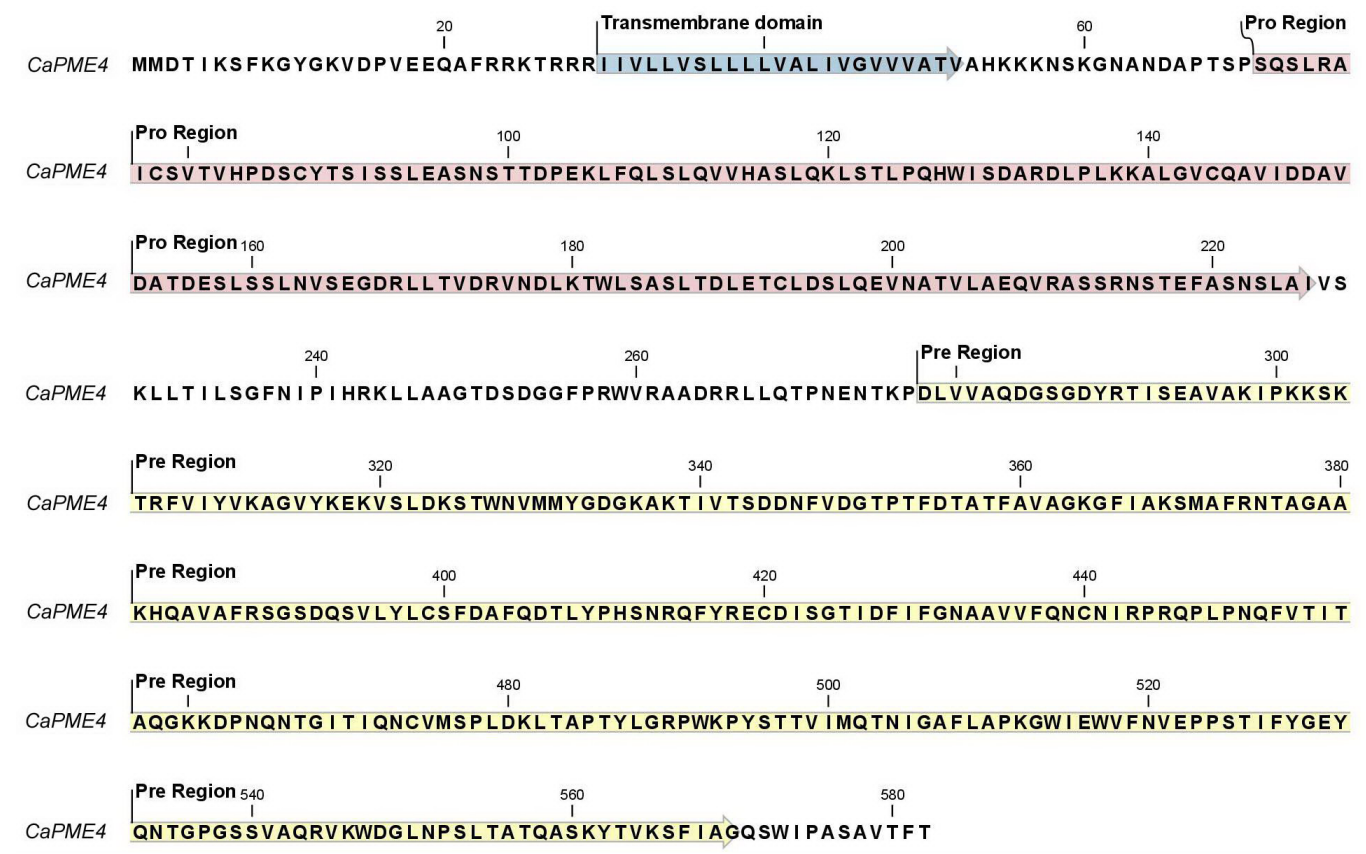

Figure 2. Predicted amino acid (aa) sequence of the Coffea arabica pectin methylesterase CaPME4. In blue is highlighted the transmembrane domain (18 aa); in red, the pro-region (156 aa) and in yellow pre-region (293 aa).

\section{Expression of CaPME4 genes in non-fruit tissues}

Since PME is part of a multi-gene family, transcription in different plant tissues and stages of development as well as constitutive expression of some isoforms have been reported (Markovic and Janecek, 2004; Kim et al., 2010). Therefore, CaPME4 transcript accumulation was investigated in the fully opened flower, flower bud, leaf, root, and young and old branches of C. arabica cv. IAPAR-59 (Figure 3). CaPME4 transcripts were highly expressed in branches and roots with lower expression in flower buds. The presence of these transcripts 
in branches and roots is probably due to cell-wall extension, cellular separation, internode stem growth, and root-tip elongation (Sobry et al., 2005).

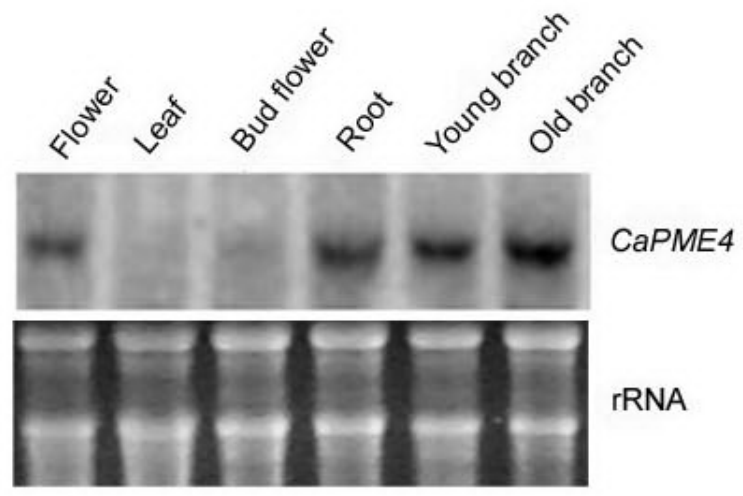

Figure 3. Northern blot of CaPME4 in different coffee tissues. Total RNA stained with ethidium bromide was used to monitor the equal loading of the samples.

\section{CaPME4 expression during fruit development and ripening and PME activity}

We investigated the transcriptional pattern of CaPME4 in coffee fruit tissues at different developmental and ripening stages in the pericarp (90-300 DAF), perisperm (90-150 DAF), and endosperm (90-300 DAF) (Figure 4). Expression of this isoform was observed in the pericarp only at $210 \mathrm{DAF}$, reaching a maximum at the final stages of ripening (300 DAF, cherry fruit). It is important to note that no transcriptional activity of $C a P M E 4$ was detected in over-ripened fruits (dark cherry). At this stage, the coffee fruit is characterized by endosperm dehydration and alteration in pericarp color (De Castro and Marraccini, 2006). CaPME4 signal was not observed in the perisperm, and a faint band was only detected at 270 DAF in the endosperm (seed).

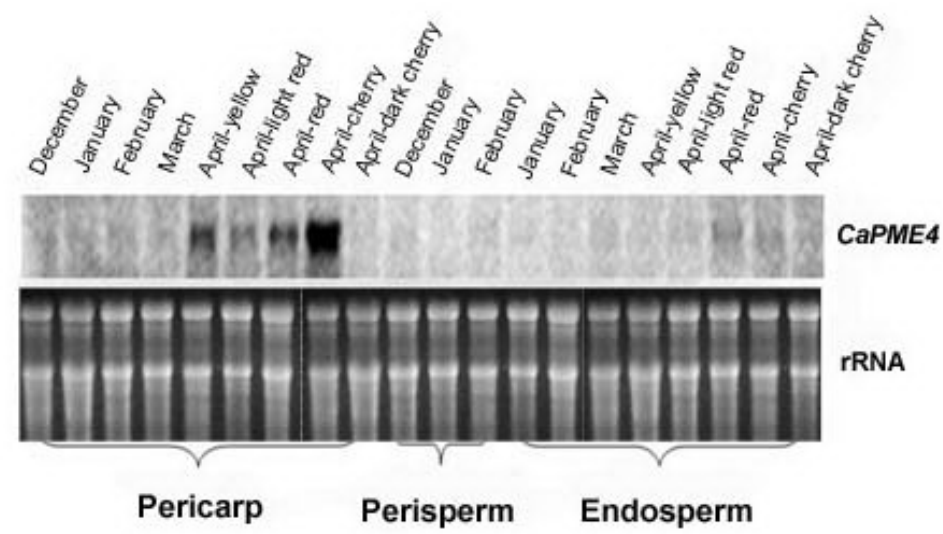

Figure 4. Northern blot of CaPME4 during fruit development. Total RNA from the pericarp, perisperm and endosperm of Coffea arabica cv. IAPAR-59 from different stages of fruit development and ripening. Fruits were monthly collected: December to April. Different stages of fruit ripening were also collected during April according to fruit colors. December [90 days after flowering (DAF)], January (120 DAF), February (150 DAF), March (180 DAF), and April (210-300 DAF). Total RNA stained with ethidium bromide was used to monitor the equal loading of the samples. 
PME activity increased progressively from the initial stage until the last stage of fruit ripening, which corresponds with the transcription analysis that showed maximum CaPME4 mRNA expression in the pericarp at the cherry stage (Figures 4 and 5). The accumulation of early transcripts of one isoform of $P M E$ coupled with PME activity suggests that this $P M E$ is involved in cell expansion during the initial phase of development of the pericarp. PME activity before color change of the pericarp in coffee may also reflect signal induction in this climacteric fruit. Although PME is part of a large multi-gene family with functional redundancy, the isoform analyzed here is a strong candidate for further studies of coffee fruit development and ripening. Similar to our results, PME activity has been reported in several ripening climacteric fruits, including kiwifruit, papaya, avocado, and peach (Redgwell et al., 1990; Paull et al., 1999; Wakabayashi et al., 2000; Brummel et al., 2004).

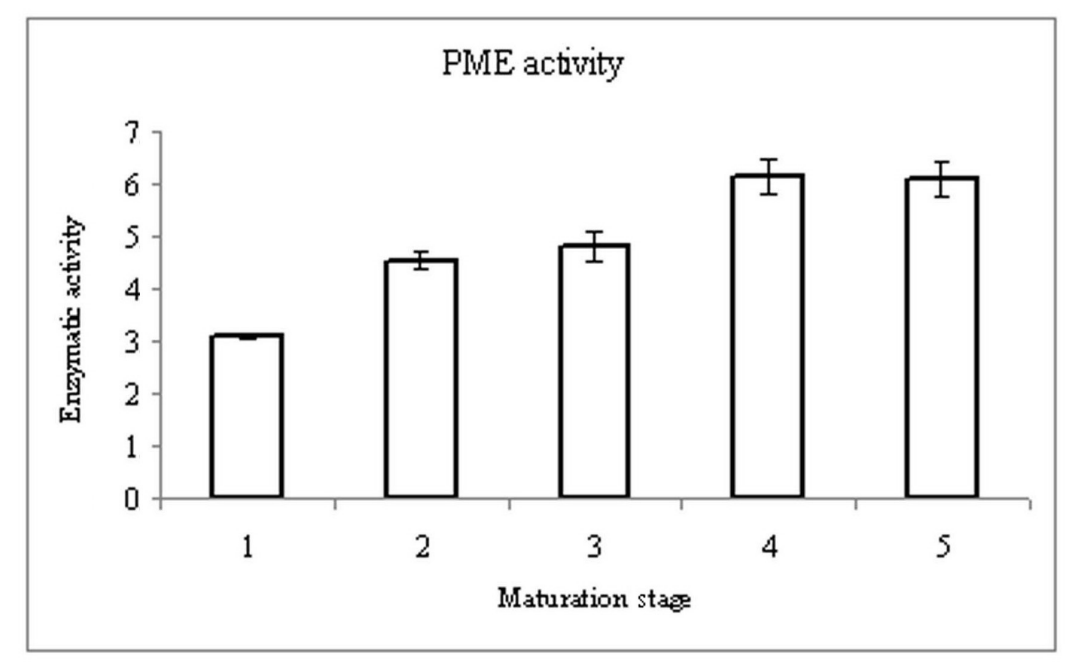

Figure 5. Specific activity of pectin methylesterases (PME) in different maturation stages of the coffee fruit, classified by the pericarp color: 1 - green [120 days after flowering (DAF)], 2 - light red (210 DAF), 3 - red (240 DAF), 4 - cherry (270 DAF), 5 - dark cherry (300 DAF). PME activity in mol of carboxyl groups in fresh weight pericarp $\mathrm{g}^{-1} \cdot \mathrm{min}^{-1}$.

During the ripening process, there are complex changes in the fruit wall due to the presence of cell wall softening enzymes and/or enzymatic inhibitors (Ali et al., 2004). Substantial synthesis of methyl-esterified pectin during the green stages and the increase in cell number and volume underlie the presence of high PME activity at early stages (Draye and Van Cutsem, 2008). PME catalyzes the hydrolysis of pectin methyl ester groups, resulting in de-esterification, which contributes directly or indirectly to the action of other enzymes by creating an appropriate ionic environment or possibly by modifying the cell wall porosity to increase the access of other enzymes to their substrates. PME preferentially attacks methyl ester bonds of galacturonate units next to non-esterified galacturonate units (Pilnik and Voragen, 1970), which precedes the activity of polygalacturonase (PG) (Koch and Nevins, 1989). In papaya, PME activity increased during maturation, which was followed by elevation of PG activity and decreased pulp texture (Lazan et al., 1995). In coffee fruits, PG activity is increased in the pericarp during the latest stages of ripening (Cação et al., 2003). 
Coffee fruits have unusual tissue organization and development. The developing endosperm progressively replaces the perisperm inside locules; this process is almost complete by 120-150 DAF, while the remaining perisperm resembles a thin pellicle surrounding the endosperm. The storage phase, when cell walls of the endosperm begin to thicken due to the deposition of complex polysaccharides, occurs 130-190 DAF (De Castro and Marraccini, 2006). Towards the end of coffee fruit maturation, when endosperm development is complete, the final process of ripening is initiated. In climacteric fruits like coffee, a burst of ethylene occurs, followed by an increase in size and a change in color of the pericarp (Pereira et al., 2005). Our results showed an increased of both transcript level and enzymatic activity of PME during ripening (210-300 DAF) concomitant with development of the pericarp (Figures 4 and 5).

In this study, we showed that the CaPME4 isoform acts specifically during the later stages of fruit ripening. This may contribute to coffee fruit softening, suggesting that CaPME4 plays a significant role in pectin degradation in the fruit pericarp. As a result, the CaPME4 gene could be an early molecular marker for color change of the pericarp and, consequently, for coffee fruit maturation.

\section{ACKNOWLEDGMENTS}

Research supported by the Brazilian Consortium for Coffee Research, National Council for Scientific and Technological Development (CNPq). S.M.B. Cação was the recipient of a student fellowship from CNPq-INCT Café. L.F.P. Pereira and L.G.E. Vieira were recipients of fellowships from CNPq.

\section{REFERENCES}

Ali ZM, Chin L-H and Lazan H (2004). A comparative study on wall degrading enzymes, pectin modifications and softening during ripening of selected tropical fruits. Plant Sci. 167: 317-327.

Altschul SF, Madden TL, Schaffer AA, Zhang J, et al. (1997). Gapped BLAST and PSI-BLAST: a new generation of protein database search programs. Nucleic Acids Res. 25: 3389-3402.

Brummell DA, Dal Cin V, Crisosto CH and Labavitch JM (2004). Cell wall metabolism during maturation, ripening and senescence of peach fruit. J. Exp. Bot. 55: 2029-2039.

Budzinski IG, Santos TB, Sera T, Pot D, et al. (2011). Expression patterns of three alpha-expansin isoforms in Coffea arabica during fruit development. Plant Biol. 13: 462-471.

Cação SMB, Galvão RM, Pereira LFP and Vieira LGE (2003). Identificação e Caracterização de Genes de Poligalacturonase de Coffea arabica. In: Anais do III Simpósio de Pesquisa dos Cafés do Brasil Embrapa Café, Porto Seguro, 98-99.

De Castro RD and Marraccini P (2006). Cytology, biochemistry and molecular changes during coffee fruit development. Braz. J. Plant Physiol. 18: 175-199.

Derbyshire P, McCann MC and Roberts K (2007). Restricted cell elongation in Arabidopsis hypocotyls is associated with a reduced average pectin esterification level. BMC Plant Biol. 7: 31.

Dorokhov YL, Skurat EV, Frolova OY, Gasanova TV, et al. (2006). Role of the leader sequence in tobacco pectin methylesterase secretion. FEBS Lett. 580: 3329-3334.

Draye M and Van Cutsem P (2008). Pectin methylesterases induce an abrupt increase of acidic pectin during strawberry fruit ripening. J. Plant Physiol. 165: 1152-1160.

Geromel C, Ferreira LP, Guerreiro SM, Cavalari AA, et al. (2006). Biochemical and genomic analysis of sucrose metabolism during coffee (Coffea arabica) fruit development. J. Exp. Bot. 57: 3243-3258.

Giovane A, Servillo L, Balestrieri C, Raiola A, et al. (2004). Pectin methylesterase inhibitor. Biochim. Biophys. Acta 1696: 245-252.

Jolie RP, Duvetter T, Van Loey AM and Hendrickx ME (2010). Pectin methylesterase and its proteinaceous inhibitor: a review. Carbohydr. Res. 345: 2583-2595.

Kertesz ZI (1955). Pectic Enzymes. In: Methods of Enzymology (Clowick SP and Kaplan NO, eds.). Academic Press,

Genetics and Molecular Research 11 (3): 3186-3197 (2012)

CFUNPEC-RP www.funpecrp.com.br 
New York, 158.

Kim HB, Jun S-S, Choe S, Cho JY, et al. (2010). Identification of differentially expressed genes from male and female flowers of kiwifruit. J. Biotechnol. 9: 6684-6694.

Koch JL and Nevins DJ (1989). Tomato fruit cell wall: I. Use of purified tomato polygalacturonase and pectinmethylesterase to identify developmental changes in pectins. Plant Physiol. 91: 816-822.

Körner B, Zimmerman G and Berk Z (1980). Orange pectinesterase: purification, properties and effects on cloud stability. J. Food Sci. 45: 1203-1206.

Lazan H, Selamat MK and Ali ZM (1995). Beta-galactosidase, polygalacturonase and pectinesterase in differential softening and cell wall modification during papaya fruit ripening. Physiol. Plant. 95: 106-112.

Markovic O and Janecek S (2004). Pectin methylesterases: sequence-structural features and phylogenetic relationships. Carbohydr. Res. 339: 2281-2295.

Micheli F (2001). Pectin methylesterases: cell wall enzymes with important roles in plant physiology. Trends Plant Sci. 6: 414-419.

Micheli F, Sundberg B, Goldberg R and Richard L (2000). Radial distribution pattern of pectin methylesterases across the cambial region of hybrid aspen at activity and dormancy. Plant Physiol. 124: 191-199.

Mondego JM, Vidal RO, Carazzolle MF, Tokuda EK, et al. (2011). An EST-based analysis identifies new genes and reveals distinctive gene expression features of Coffea arabica and Coffea canephora. BMC Plant Biol. 11: 30.

Montavon P, Duruz E, Rumo G and Pratz G (2003). Evolution of green coffee protein profiles with maturation and relationship to coffee cup quality. J. Agric. Food Chem. 51: 2328-2334.

Paull RE, Gross K and Qiu YX (1999). Changes in papaya cell walls during fruit ripening. Postharvest Biol. Technol. 16: 79-89.

Pereira LFP, Galvão RM, Kobayashi AK, Cação SMB, et al. (2005). Ethylene production and acc-oxidase gene expression during fruit ripening of Coffea arabica L. Braz. J. Plant Physiol. 17: 283-289.

Pilnik W and Voragen AGJ (1970). Pectic Substances and Other Uronides. In: The Biochemistry of Fruits and Their (Hulme AC, ed.). Products Academic Press, London and New York, 53-87.

Pimenta CJ, Chagas SJR and Costa L (2000). Pectinas e enzimas pectinolíticas em café (Coffea arábica) colhido em quatro estádios de maturação. Cienc. Agrotecnol. 24: 1079-1183.

Prasanna V, Prabha TN and Tharanathan RN (2007). Fruit ripening phenomena-an overview. Crit. Rev. Food Sci. Nutr. 47: 1-19.

Redgwell RJ, Melton LD and Brasch DJ (1990). Cell wall changes in Kiwifruit following post harvest ethylene treatment. Phytochemistry 29: 399-407.

Ren C and Kermode AR (2000). An increase in pectin methyl esterase activity accompanies dormancy breakage and germination of yellow cedar seeds. Plant Physiol. 124: 231-242.

Rena AB, Nacif AP, Gontijo PTG and Pereira AA (1996). Fisiologia do Cafeeiro em Plantios Adensados. In: Simpósio Internacional Sobre Café Adensado (Caramori PH, Androcioli A, Liberal EG, Chaves JCD, et al., eds.). Londrina, $72-85$.

Ribas AF, Pereira LFP and Vieira LGE (2006). Genetic transformation of coffee. Braz. J. Plant Physiol. 18: 83-94.

Roberts JA, Whitelaw CA, Gonzalez-Carranza ZH and McManus MT (2000). Cell separation process in plants: models, mechanisms and manipulations. Ann. Bot. 86: 223-235.

Sambrook J, Fritsch EF and Maniatis T (1989). Molecular Cloning: A Laboratory Manual. 2nd edn. Cold Spring Harbor Laboratory, Cold Spring Harbor, New York.

Siedlecka A, Wiklund S, Péronne M-A, Micheli F, et al. (2008). Pectin methyl esterase inhibits intrusive and symplastic cell growth in developing wood cells of Populus. Plant Physiol. 146: 554-565.

Sobry S, Havelange A and Van Cutsem P (2005). Immunocytochemistry of pectins in shoot apical meristems: consequences for intercellular adhesion. Protoplasma 225: 15-22.

Tamura K, Peterson D, Peterson N, Stecher G, et al. (2011). MEGA5: Molecular evolutionary genetics analysis using maximum likelihood, evolutionary distance, and maximum parsimony methods. Mol. Biol. Evol. 28: 2731-2739.

Tieman DM and Handa AK (1994). Reduction in pectin methylesterase activity modifies tissue integrity and cation levels in ripening tomato (Lycopersicon esculentum Mill.) fruits. Plant Physiol. 106: 429-436.

Vieira LGE, Andrade AC, Colombo CA, Moraes AHA, et al. (2006). Brazilian coffee genome project: an EST-based genomic resource. Braz. J. Plant Physiol. 18: 95-108.

Wakabayashi K, Chun JP and Huber DJ (2000). Extensive solubilization and depolymerization of cell wall polysaccharides during avocado (Persea americana) ripening involves concerted action of polygalacturonase and pectinmethylesterase. Physiol. Plant. 108: 345-352. 